\title{
Application of skimmed milk freeze concentrated in production of ice cream: physical, chemical, structural and rheological properties
}

\author{
Callebe CAMELO-SILVA ${ }^{1}$ (D), Eulália Lopes da Silva BARROS ${ }^{1}$, Maria Helena Machado CANELLA², \\ Silvani VERRUCK ${ }^{2}$, Amanda Alves PRESTES ${ }^{1}$, Maryella Osório VARGAS ${ }^{2}$, Bruna Marchesan MARAN ${ }^{3}$, \\ Erick Almeida ESMERINO ${ }^{4}$, Ramon SILVA ${ }^{4}$, Celso Fasura BALTHAZAR ${ }^{4}$, Veronica Maria de Araujo CALADO ${ }^{5}$, \\ Elane Schwinden PRUDÊNCIO ${ }^{1,2^{*}}$
}

\begin{abstract}
Freeze concentration process was used to concentrate milk until the third stage of freeze concentration. Thus, two samples of ice creams were manufacture, one with milk and the other with concentrated milk from the first stage of block freeze concentration, and denominated ice cream 1 and ice cream 2, respectively. Both ice creams were characterized according to physicochemical characteristics, overrun, microscopy, melting rate, texture, color, and rheological properties. The use of concentrated milk influenced the physicochemical properties of ice cream 2, promoting an increase in the total solids, protein, carbohydrates, and ashes content. Moreover, it was noted that ice cream 2 had a higher overrun, lower firmness, smaller ice crystals, and tended to color greenish and yellowish, however had a higher melting rate and larger hysteresis area. The models of the Power Law and Casson satisfactorily described the rheological behavior of ice creams, which proved to be a Newtonian fluid.
\end{abstract}

Keywords: concentrated milk; ice cream; physical properties; rheology; power law model; casson model.

Practical Application: The potential use of concentrated skimmed milk in the manufacture of ice cream.

\section{Introduction}

Ice cream is considered the most known milk dessert worldwide, reaching a global consumption of $2 \mathrm{~L}$ per person/ year (Góral et al., 2018). This food is a complex aerated emulsion containing milk proteins and fats that have an important role in stabilizing its structure. This matrix is formed by a frozen phase containing air bubbles, fat particles, and ice crystals (Balthazar et al., 2017; Ayed et al., 2018; Grigio et al., 2019). According to Góral et al. (2018), the primary ingredient in ice cream is cow's milk, which contains several beneficial substances for the human body, such as protein, fat, lactose, vitamins, and mineral compounds.

To concentrate these milk substances, the technology of freeze concentration stands out, since it is known as the best concentration method in terms of preserving the original quality of the product. Therefore, this technology uses low temperatures during the process, avoiding undesirable chemical, physical and biological changes that occur in other types of processing (Gunathilake et al., 2014). There are different methods of freeze concentration, such as progressive, suspension, and block freeze concentration (Ding et al., 2019; Henao-Ardila et al., 2019), however, the first and second are more complex systems. Thus, it favors the use of block freeze concentration, because it has easier handling and also, is economically more viable (Aider et al.,
2009). The principle of this method is based on the complete freezing of a solution, followed by a partial thawing process. With this method, it is possible to obtain two fractions: the first is a concentrated solution (feed solution) and the second is an ice fraction with minimum solids content. In addition, the process can be repeated in successive stages to increase the concentration efficiency. Therefore, the efficiency of the process depends mainly on the purity of the ice fraction (Aider et al., 2009).

It has been verified by Balde \& Aider (2016) that the process of freeze concentration was able to modify the availability of milk components, such as proteins, fats, ashes, and carbohydrates. Thus, it is hypothesized that the use of concentrated influences the physical and physicochemical properties of ice cream. Thus, it is important to determine these properties for a better understanding of the changes that occur in the product due to the interaction between milk components and the ingredients used in the formulation. In addition, the determination of these properties will serve as support to researchers and industries that want to employ concentrated milk in the production of ice cream.

In this context, in order to produce ice cream with higher nutritional value and better physical properties, the method of block freeze concentration was used. Thus, the objective of this work was to employ the concentrated milk obtained from

${ }^{1}$ Programa de Pós-graduação em Engenharia de Alimentos, Universidade Federal de Santa Catarina - UFSC, Florianópolis, SC, Brasil

${ }^{2}$ Departamento de Ciência e Tecnologia de Alimentos, Universidade Federal de Santa Catarina - UFSC, Florianópolis, SC, Brasil

${ }^{3}$ Departamento de Engenharia Química e Engenharia de Alimentos, Universidade Federal de Santa Catarina - UFSC, Florianópolis, SC, Brasil

${ }^{4}$ Faculdade de Veterinária, Universidade Federal Fluminense - UFF, Niterói, RJ, Brasil

${ }^{5}$ Escola de Química, Universidade Federal do Rio de Janeiro - UFRJ, Rio de Janeiro, RJ, Brasil

*Corresponding author: elane.prudencio@ufsc.br 
the process of block freeze concentration to produce ice cream, as well as to evaluate its chemical, physical, rheological, and microstructural properties.

\section{Material and Methods}

\subsection{Material}

For the production of concentrated milk it was used skimmed milk (Tirol ${ }^{\circledR}$, Treze Tílias, SC, Brazil) with carbohydrate, protein, lipid and total solids contents of 4.5, 3.15, 0.0, and $8.05 \mathrm{~g}$ per $100 \mathrm{~mL}$ of skimmed milk, respectively. This same milk was used to manufacture the ice creams, besides other ingredients like sucrose (União ${ }^{\circledR}$, São Paulo, SP, Brazil), milk cream (45\% fat, Tirol $^{\circledR}$, Treze Tílias, SC, Brazil), and sodium chloride (Cristalino ${ }^{\circledR}$, Mossoró, RN, Brazil) were used. All the chemicals used were of analytical grade.

\subsection{Freeze concentration procedure}

The block freeze concentration technology was used for the skimmed milk concentration, according to the methodology established by the research group. This method is based on the total freezing of a solution and its subsequent partial thawing by simple gravitational separation. With this, at the end of each stage it is possible to obtain two fractions denominated concentrated fluid $\left(\mathrm{C}_{\mathrm{n}}\right)$ and concentrated ice $\left(\mathrm{I}_{\mathrm{n}}\right)$, respectively (Figure 1). Firstly, the skimmed milk was distributed in batches of $1 \mathrm{~L}$, which were divided into $250 \mathrm{~mL}$ containers and subjected to freezing $-20 \pm 2{ }^{\circ} \mathrm{C}$ in a freezer (Electrolux, FE 18, São Carlos, $\mathrm{SP}$, Brazil). Once the initial solution was completely frozen, $50 \%$ of its initial volume was thawed at a controlled temperature of $20 \pm 2{ }^{\circ} \mathrm{C}$. The thawed liquid constitutes the concentrated of the first freeze concentration stage, which was distributed again in $250 \mathrm{~mL}$ containers, frozen $-20 \pm 2{ }^{\circ} \mathrm{C}$, and subsequently used as feed solution in the second stage of freeze concentration. This procedure was performed until the third stage of freeze concentration. At the end of each stage of the freeze concentration process, an aliquot of the remaining concentrates and the ice were collected and stored at $-20 \pm 2{ }^{\circ} \mathrm{C}$ for future analyzes.

The efficiency of the freeze concentration process (PE) was determined taking into account the increase in the total solids content (TS) in the concentrated $\left(\mathrm{C}_{\mathrm{n}}\right)(\mathrm{g} / 100 \mathrm{~g})$ in relation to the total solids (TS) remaining in the concentrated ice $\left(\mathrm{I}_{\mathrm{n}}\right)(\mathrm{g} / 100 \mathrm{~g})$ of each freeze concentration stage according to Equation 1. The concentrated milk used to produce the ice cream was chosen from the results of PE.

$\operatorname{PE}(\%)=\frac{\text { TSnoC }_{n}-\text { TSno }_{n}}{\text { TSnoC }_{n}} \times 100$

\subsection{Ice cream manufacture}

Two ice creams were manufactured and denominated as ice cream 1 and ice cream 2. Ice cream 1 was prepared with skimmed milk, and ice cream 2 was prepared with concentrated milk. Both formulations were added with sucrose, milk cream, and sodium chloride, as showed in Table 1. Firstly, the ingredients were mixed and submitted to the thermal treatment at $70 \pm 2{ }^{\circ} \mathrm{C}$ for 30 minutes, followed by cooling at $8 \pm 2{ }^{\circ} \mathrm{C}$ for $24 \mathrm{~h}$. The ice creams were subjected to a stirring operation realized in an ice cream maker (Cuisinart ICE 21, New Jersey, USA). In the sequence, the formulations were distributed in polyethylene packages with a capacity of $500 \mathrm{~mL}$ and subjected to freezing at $-20 \pm 2{ }^{\circ} \mathrm{C}$ until the analyses.

\subsection{Physicochemical analysis}

The total solids content ( $\mathrm{g} / 100 \mathrm{~g})$ of skimmed milk, concentrated milk $(1,2,3)$, concentrated ice $(1,2,3)$, and in the ice creams were obtained by the oven drying method until constant weight at $105 \pm 2{ }^{\circ} \mathrm{C}$ (Association of Official Analytical Chemists, 2019). The skimmed milk, the best performing concentrate, and ice creams were analyzed in relation to the protein content (g/100 g) by the Kjeldahl method ( $\mathrm{N} x$ 6.38) (Association of Official Analytical Chemists, 2019), fat content (g/100 g) by the soxhlet method (Association of Official Analytical Chemists, 2019), ashes ( $\mathrm{g} / 100 \mathrm{~g}$ ) by the gravimetric method (Association of Official Analytical Chemists, 2019), total carbohydrate content ( $\mathrm{g} / 100 \mathrm{~g}$ ) obtained by difference (Association of Official Analytical Chemists, 2019), total titratable acidity (g/100 g lactic acid) (Association of Official Analytical Chemists, 2019) and pH using a pHmeter (PHS-3 BW, BEL, Piracicaba, São Paulo, SP, Brazil). All physicochemical analyzes were done in triplicate.

\subsection{Physical measurements}

\subsubsection{Overrun analysis}

Ice cream overrun was determined according to the methodology described by Marshall et al. (2003). For this, $120 \mathrm{~g}$ of ice cream mixture and another of ice cream were weighed

Table 1. Ingredients used to produce the ice cream from skimmed milk (Ice cream 1) and concentrated milk (Ice cream 2).

\begin{tabular}{ccc}
\hline Ingredients $(\mathrm{g} / 100 \mathrm{~g})$ & Ice cream 1 & Ice cream 2 \\
\hline Skimmed milk & 61.70 & - \\
Concentrated milk & - & 61.70 \\
Sucrose & 22.20 & 22.20 \\
Milk cream & 16.04 & 16.04 \\
Sodium chloride & 0.06 & 0.06 \\
Total of ingredients & 100.00 & 100.00 \\
\hline
\end{tabular}

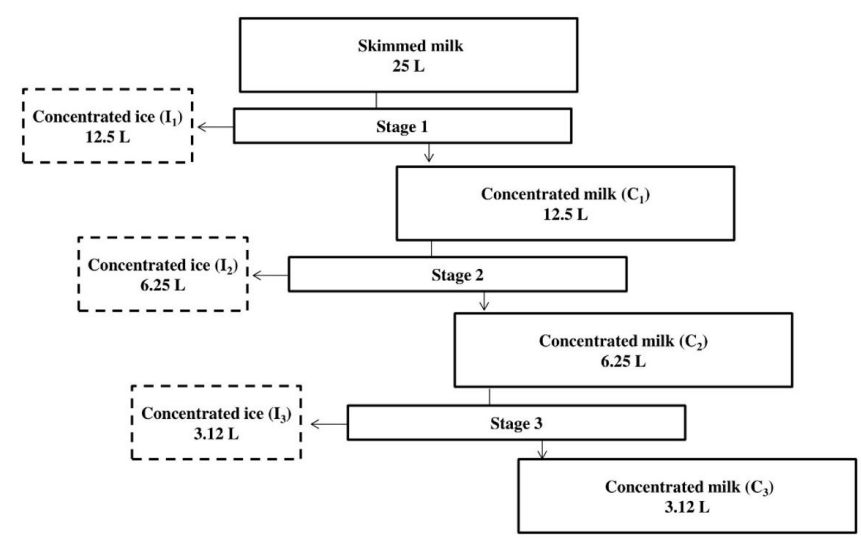

Figure 1. Diagram of the process of freeze concentration of skimmed milk. 
and the overrun was calculated using Equation 2. The analysis was performed in triplicate.

Overrun $(\%)=\frac{\text { weight of the ice cream mix }- \text { weight of the ice cream }}{\text { weight of the ice cream }} \times 100$

\subsubsection{Distribution of ice crystals, fat particle, and air bubbles} size

The ice crystals, fat particles, and air bubbles size were determined according to the Balthazar et al. (2017), using optical light microscopy (AXIO Image. A2m, Carl Zeiss, Germany) at $-4 \pm 2{ }^{\circ} \mathrm{C}$ using $50 \times$ magnification. Samples were moved directly from the freezer to the glove box $\left(-4 \pm 2{ }^{\circ} \mathrm{C}\right)$ for sample preparation. A drop of chilled kerosene was added to aid in dispersing the ice crystals and to increase the resolution of the generated image. Ice crystals, fat particles, and air bubbles images were captured by a digital camera (Axio Cam MRc 5, Zeiss, Germany) and edited using the AXIO Vision Rel. 4.8 software (Microscope Software AxioVision LE, Zeiss, Germany). For each sample, 20 structures were measured $(\mu \mathrm{m})$ in 10 microscope spots.

\subsubsection{Melting properties}

The melting of the ice creams was determined according to the methodology of Granger et al. (2005), with modifications. Approximately $50 \mathrm{~g}$ of sample, initially at $-18 \pm 2{ }^{\circ} \mathrm{C}$ were allowed to melt at $25 \pm 2{ }^{\circ} \mathrm{C}$ cover a $2 \mathrm{~mm}$ aperture wire mesh screen, above a graduated cylinder, which was about an analytical balance. The mass of drained ice cream ( $g$ ) was recorded every five minutes. From the data obtained, the melting rate was measured as the mass of the drip versus the time. The analysis was performed in triplicate.

\subsubsection{Texture analysis}

Ice creams texture analyss were measured using a TA.HD. plus model texturometer (Stable Micro System, Texture Expert, Surrey, UK), operating with the Exponent program version 6.1.1.0. Ice cream samples were stored at $-18 \pm 2{ }^{\circ} \mathrm{C}$ for $24 \mathrm{~h}$ before texture analysis. The operation parameters of the analysis were: test speed of $2.0 \mathrm{~mm} / \mathrm{s}$; a distance of $10.0 \mathrm{~mm}$, and height of $20 \mathrm{~mm}$. The parameters obtained were: firmness $(\mathrm{N})$, adhesiveness (N.s), and gumminess $(\mathrm{N})$. The analysis was repeated five times for each sample.

\subsubsection{Color analysis}

The color analysis of the ice creams were determined using the Minolta Chroma Meter CR-400 colorimeter (Konica Minolta, Osaka, Japan), adjusted to operate with illuminant D65 and $10^{\circ}$ angle observation. Firstly, the colorimeter was calibrated with a standard whiteboard, and to measure the parameters $L^{*}, a^{*}$, and $b^{*}$ was used the CIELab color scale. The total color difference $\left(\Delta \mathrm{E}^{\star}\right)$ between ice creams was determined according to Okpala et al. (2010), as described in Equation 3. The analysis was performed in triplicate.
$\Delta \mathrm{E}^{*}=\sqrt{\left(\Delta \mathrm{L}^{*}\right)^{2}+\left(\Delta \mathrm{a}^{*}\right)^{2}+\left(\Delta \mathrm{b}^{*}\right)^{2}}$

Where $\Delta \mathrm{L}^{*}$ is the luminosity difference, while $\Delta \mathrm{a}^{*}$ represents the intensity of the red color and $\Delta \mathrm{b}^{*}$ the intensity of the yellow color.

\subsubsection{Rheological analysis}

The rheological analysis of ice creams were determined on a Brookfield rotational rheometer with concentric cylinders (Brookfield Engineering Laboratories, model DVIII Ultra, Stoughton, USA) and spindle ULA. The measurements were collected using Rheocalc ${ }^{\circledR} 32$ software version 3.2 (Brookfield Engineering Laboratories, Inc., Middleboro, MA, USA). The rheometer was thermostatically controlled by a water bath (TECNAL model TE-184, São Paulo, SP, Brazil) at $4.0 \pm 0.1{ }^{\circ} \mathrm{C}$. Two rheological measurements were taken to obtain the flow curves: the first with increasing shear rate from $125 \mathrm{~s}^{-1}$ to $269 \mathrm{~s}^{-1}$ in the first 4 minutes (rising curve), and the second with decreasing shear rate returning to $125 \mathrm{~s}^{-1}$ the over the following 4 minutes (downward curve). The speed of rotation was increased from $2 \mathrm{rpm}$ to $62 \mathrm{rpm}$, increasing at $2 \mathrm{rpm}$ per $30 \mathrm{~s}$. The behavior of the flow was described by Power Law and Casson models, according to Equations 4 and 5, respectively:

$\sigma=\mathrm{K}(\dot{\gamma})^{\mathrm{n}}$

$\sigma^{0.5}=\sigma_{0}^{0.5}+\left(\eta_{\mathrm{c}} \dot{\gamma}\right)^{0.5}$

where $\sigma$ is the shear stress $(\mathrm{Pa}) ; \mathrm{K}$ the consistency index $\left(\mathrm{Pa} \mathrm{s}^{-1}\right)$; $\dot{\gamma}$ is the rate of deformation $\left(\mathrm{s}^{-1}\right) ; \mathrm{n}$ is the flow behavior index (dimensionless); $\sigma_{0}$ is the Casson yield stress $(\mathrm{Pa})$ and $\eta_{c}$ is the Casson viscosity (Pa.s).

\subsection{Statistical analysis}

Statistical analysis was performed using STATISTICA 13.3 software (TIBCO Software Inc., Palo Alto, CA). Tukey test was realized to determine the significant differences $(p<0.05)$ between the samples. Data were presented as mean \pm standard deviation.

\section{Results and discussion}

\subsection{Freeze concentration procedure}

The total solids content and the efficiency of the skimmed milk freeze concentration process are shown in Table 2. It was verified an increase $(p<0.05)$ of total solids for concentrated milk and concentrated ice fractions as a function of the evolution of the freeze concentration stage. On the other hand, it was observed that the process efficiency was higher $(p<0.05)$ in the first freeze concentration stage, indicating higher total solids content in the concentrated milk fraction. These results are in accordance with those of Canella et al. (2019), which obtained higher separation efficiency of total solids goat milk in the first freeze concentration stage, resulting in a high quality concentrated. These results indicated a greater recovery of solids content in the 
Table 2. Total solids content of skimmed milk, concentrated milks (C1, C2 and C3) and concentrated ices (I1, I2 and I3) from each stage of the freeze concentration process and the efficiency of the process (PE) in relation to the total solids content.

\begin{tabular}{cccc}
\hline & & Total solids $(\mathrm{g} / 100 \mathrm{~g})$ & PE $(\%)$ \\
\hline Skimmed milk & & $8.05 \pm 0.22^{\mathrm{dB}}$ & - \\
Stage 1 & $\mathrm{C}_{1}$ & $10.27 \pm 0.10^{\mathrm{c}}$ & $90.84 \pm 0.03^{*}$ \\
& $\mathrm{I}_{1}$ & $0.94 \pm 0.01^{\mathrm{C}}$ & - \\
Stage 2 & $\mathrm{C}_{2}$ & $20.28 \pm 0.15^{\mathrm{b}}$ & $60.62 \pm 2.07^{\diamond}$ \\
& $\mathrm{I}_{2}$ & $7.99 \pm 0.41^{\mathrm{B}}$ & - \\
Stage 3 & $\mathrm{C}_{3}$ & $21.52 \pm 0.18^{\mathrm{a}}$ & $23.05 \pm 0.28^{\circ}$ \\
& $\mathrm{I}_{3}$ & $16.56 \pm 0.12^{\mathrm{A}}$ & - \\
\hline
\end{tabular}

Results expressed as mean \pm standard deviation; ${ }^{\text {a-d }}$ Within a column, different superscript lowercase letters denote significant differences $(p<0.05)$ between skimmed milk and concentrated milks at each stage of freeze concentration; ${ }^{\mathrm{A}-\mathrm{C}}$ Within a column, different superscript uppercase letters denote significant differences ( $\left.p<0.05\right)$ between skimmed milk and concentrated ice at each stage of freeze concentration; ${ }^{(* \bullet \bullet)}$ Within a column, different symbols denote significant differences $(p<0.05)$ in the PE of each stage of freeze concentration.

Table 3. Physicochemical properties of skimmed milk, concentrated milk, and of the ice creams produced from skimmed milk (Ice cream 1) and concentrated milk (Ice cream 2).

\begin{tabular}{|c|c|c|c|c|}
\hline Analyzes & Skimmed milk & Concentrated milk & Ice cream 1 & Ice cream 2 \\
\hline Total solids $(\mathrm{g} / 100 \mathrm{~g})$ & $8.05 \pm 0.22$ & $10.27 \pm 0.01$ & $33.82 \pm 0.07^{\mathrm{b}}$ & $37.30 \pm 0.6^{\mathrm{a}}$ \\
\hline Protein $(\mathrm{g} / 100 \mathrm{~g})$ & $3.15 \pm 0.02$ & $7.07 \pm 0.40$ & $2.43 \pm 0.1^{\mathrm{b}}$ & $4.92 \pm 0.1^{\mathrm{a}}$ \\
\hline Fat $(\mathrm{g} / 100 \mathrm{~g})$ & $0.16 \pm 0.01$ & $0.18 \pm 0.05$ & $6.80 \pm 0.61^{\mathrm{a}}$ & $7.13 \pm 0.06^{\mathrm{a}}$ \\
\hline Ashes (g/100 g) & $0.39 \pm 0.03$ & $1.29 \pm 0.19$ & $0.61 \pm 0.02^{\mathrm{b}}$ & $1.09 \pm 0.01^{\mathrm{a}}$ \\
\hline Carbohydrates (g/100 g) & $4.35 \pm 0.01$ & $1.73 \pm 0.01$ & $23.98 \pm 0.01^{\mathrm{b}}$ & $24.16 \pm 0.02^{\mathrm{a}}$ \\
\hline $\mathrm{pH}$ & $6.81 \pm 0.02$ & $6.66 \pm 0.01$ & $6.72 \pm 0.02^{\mathrm{a}}$ & $6.65 \pm 0.01^{\mathrm{b}}$ \\
\hline Total titratable acidity (g/100 g lactic acid) & $0.20 \pm 0.01$ & $0.53 \pm 0.01$ & $0.17 \pm 0.01^{\mathrm{b}}$ & $0.29 \pm 0.03^{\mathrm{a}}$ \\
\hline
\end{tabular}

Results expressed as mean \pm standard deviation; ${ }^{\text {a-b }}$ Within a line, different superscript lowercase letters denote significant differences $(p<0.05)$ between the ice cream samples.

first freeze concentration stage. However, the process efficiency in the second and third freeze concentration stage decreased significantly, indicating that a relatively large content of total solids was retained in the concentrated ice fraction. Sánchez et al. (2011) and Raventós et al. (2007) affirmed that with the total solids content increases, the viscosity of the concentrated solution also increases, and due to the increased viscosity of the concentrated solution, solids tend to accumulate at the ice-liquid interface (concentration polarization) and the diffusion of these solids between the interface is slower, causing these solids being retained in the ice fraction and thus contributing to reducing the efficiency of the freeze concentration process. Therefore, the concentrated milk of the first stage of freeze concentration was used in the manufacture of ice cream, as it presented higher process efficiency.

\subsection{Physicochemical analysis}

Table 3 shows the results of the physicochemical properties of skimmed milk, concentrated milk, and ice creams. It was observed that ice cream 2 had a higher $(p<0.05)$ content of total solids, proteins, ashes, and carbohydrates than ice cream 1 . However, there was no difference $(p>0.05)$ in lipid content between the ice creams. This behavior could be explained by the use of skimmed milk in the manufacture of the ice creams, and the amount of fat added during the formulation was the same in both ice creams. The higher value of total solids content, proteins, ashes, and carbohydrates for ice cream 2 was expected due to the concentration method used in the milk. The total solids contents found in this work for ice creams are in agreement with those obtained by Mostafavi et al. (2017) for low-fat ice creams containing milk protein concentrated. The protein content of ice cream 2 was higher $(p<0.05)$ than ice cream 1 (Table 3 ), which is the typical range reported for ice creams in many studies (Cruxen et al., 2017; Senaka Ranadheera et al., 2013; Silva et al., 2015). A higher value in protein content in ice cream 2 contributes significantly to the development of the structure of ice cream since milk proteins contribute to air stabilization at the ice cream interface, emulsification, and water holding capacity, as verified by Patel et al. (2006). The ash content for both ice creams was similar to Cruxen et al. (2017) when worked with probiotic ice cream added with butiá pulp. The carbohydrate content was similar to those of Di Criscio et al. (2010) when studying symbiotic ice cream added inulin and Lacticaseibacillus case $i$ and Lacticaseibacillus rhamnosus. The $\mathrm{pH}$ value was higher $(p<0.05)$ for ice cream 1. Thus, Marshall et al. (2003) mentioned that the total titratable acidity and $\mathrm{pH}$ value of ice cream are related to the total solids content because an increase in total solids promotes an increase in acidity, and decreases $\mathrm{pH}$, as verified in the present work. Mostafavi et al. (2017) confirmed that the total titratable acidity of milk depends on the nitrogen values of casein, albumin, phosphates, citrates, carbon dioxide, and when the protein content of ice cream increases, the nitrogen content increases causing an increase in the value of total titratable acidity, confirming the higher value of total titratable acidity $(p<0.05)$ for the ice cream 2 determined in this study.

\subsection{Overrun analysis}

Table 4 shows that ice cream 2 had a higher $(p<0.05)$ overrun value than ice cream 1 . This event can be attributed to the physicochemical composition of the ice cream 2, especially the protein content, which was higher $(p<0.05)$ for the ice cream produced with the concentrated milk of the first stage of 
(A)

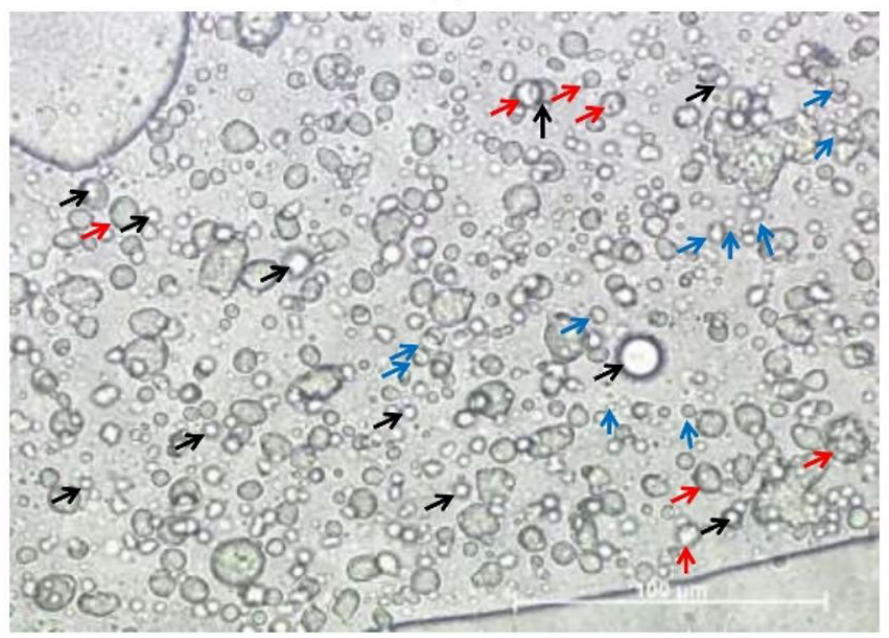

(B)

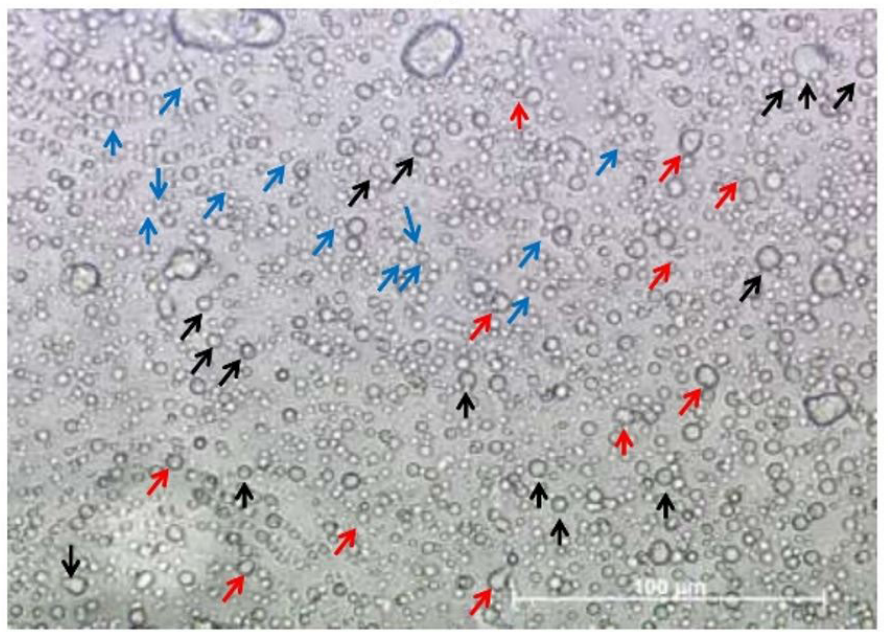

Figure 2. Distribution of ice crystals, fat particles, and air bubbles of the ice creams produced from skimmed milk (Ice cream 1) and concentrated milk (Ice cream 2). (A) = Ice Cream 1. (B) = Ice Cream 2. Black arrows represent air bubbles; Blue arrows represent fat particles; Arrows in red represent ice crystals.

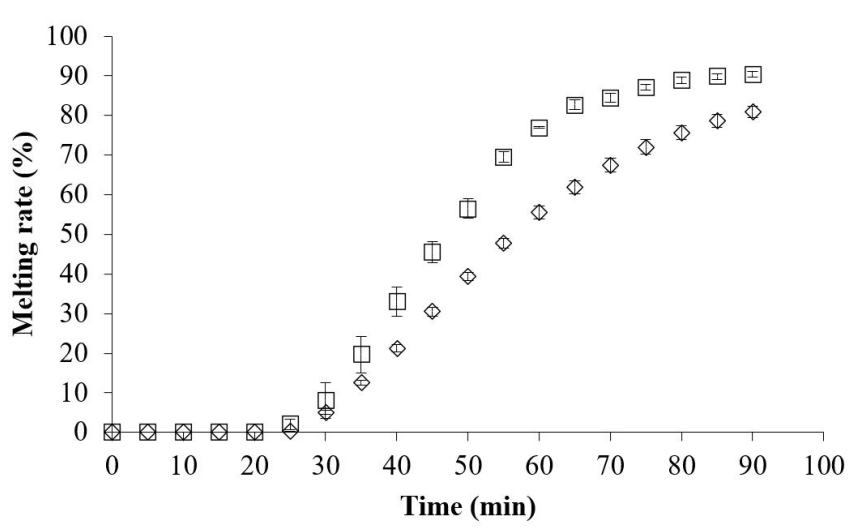

Figure 3. Melting rate of the ice creams produced from skimmed milk (Ice cream 1) and concentrated milk (Ice cream 2). $\diamond=$ Ice cream 1. $\square=$ Ice cream 2 .

Table 4. Physical properties and parameter color $\left(\mathrm{L}^{*}, \mathrm{a}^{*}, \mathrm{~b}^{*}\right.$, and $\Delta \mathrm{E}$ ) of ice creams produced from skimmed milk (Ice cream 1) and concentrated milk (Ice cream 2).

\begin{tabular}{ccr}
\hline & Ice cream 1 & Ice cream 2 \\
\hline Overrun $(\%)$ & $26.96 \pm 0.85^{\mathrm{b}}$ & $63.71 \pm 6.89^{\mathrm{a}}$ \\
Ice crystals $\left(\mu \mathrm{m}^{2}\right)$ & $43.75 \pm 16.45^{\mathrm{a}}$ & $16.99 \pm 7.37^{\mathrm{b}}$ \\
Fat particle $(\mu \mathrm{m})$ & $2.52 \pm 0.71^{\mathrm{a}}$ & $1.82 \pm 0.32^{\mathrm{a}}$ \\
Air bubbles $(\mu \mathrm{m})$ & $3.90 \pm 1.40^{\mathrm{a}}$ & $3.24 \pm 0.94^{\mathrm{a}}$ \\
Firmness $(\mathrm{N})$ & $29.55 \pm 6.16^{\mathrm{a}}$ & $5.88 \pm 1.46^{\mathrm{b}}$ \\
Adhesiveness $(\mathrm{N} \mathrm{s})$ & $-1.55 \pm 0.47^{\mathrm{a}}$ & $-1.39 \pm 0.50^{\mathrm{a}}$ \\
Gumminess $(\mathrm{N})$ & $1.21 \pm 0.20^{\mathrm{a}}$ & $0.55 \pm 0.07^{\mathrm{b}}$ \\
$\mathrm{L}^{*}$ & $83.77 \pm 0.43^{\mathrm{b}}$ & $84.95 \pm 0.63^{\mathrm{a}}$ \\
$\mathrm{a}^{*}$ & $-2.87 \pm 0.03^{\mathrm{b}}$ & $-3.79 \pm 0.04^{\mathrm{a}}$ \\
$\mathrm{b}^{*}$ & $14.31 \pm 0.11^{\mathrm{b}}$ & $15.90 \pm 0.39^{\mathrm{a}}$ \\
$\Delta \mathrm{E}$ & 2.17 & \\
\hline
\end{tabular}

Results expressed as mean \pm standard deviation; ${ }^{\mathrm{a}-\mathrm{b}}$ Within a line, different superscript lowercase letters denote significant differences $(p<0.05)$ between the ice cream samples. freeze concentration. It was noted by Huppertz (2010) that milk proteins have high air retention capacity, thus providing a greater overrun. Góral et al. (2018) verified that the low overrun in the ice cream was due to the low protein content in the samples. On the other hand, the overrun is also related to the melting rate, since was confirmed by Senanayake et al. (2013) that fruit ice creams with a low percentage of overrun tend to have a lower melting rate, as confirmed in the present work. Similar results were observed by Soukoulis et al. (2008) for vanilla ice cream added with hydrocolloids and their blends with $\kappa$-carrageenan.

\subsection{Distribution of ice crystals, fat particle, and air bubbles size}

Table 4 and Figure 2 show the size and distribution of ice crystals, fat particles, and air bubbles, respectively. It can be observed that ice cream 1 presented a larger size of ice crystals $(p<0.05)$. According to Kamińska-Dwórznicka et al. (2019), ice crystals should be less than $50 \mu \mathrm{m}$ to avoid consumer rejection, thus, sizes smaller than this value were observed for both ice creams. This difference in ice crystal size can be attributed to the protein content because it was verified by Lomolino et al. (2020) that ice cream samples which contain a higher amount of milk protein, either in powdered or concentrated form and combined with a polysaccharide-rich stabilizer, favored the development of smaller ice crystals in ice cream during freezing. Balthazar et al. (2017) noted similar ice crystal sizes for sheep milk ice cream. Concerning fat particle size and air bubble diameter, there was no difference $(p>0.05)$ between the samples.

\subsection{Melting properties}

It was observed that ice cream 2 showed a higher $(p<0.05)$ melting rate than ice cream 1 (Figure 3). Kalicka et al. (2019) defined that the melting is the degree to which the sample resists flow under an applied force in the mouth. Sofjan \& Hartel 
(2004) affirmed that ice cream melting rate could be influenced by many factors including the overrun, total solids, ice crystal size, lipid, and protein content. Muse \& Hartel (2004) reported that initially the ice melts outside the ice cream and there is a local cooling effect. Melted ice water diffuses into the viscous phase, and this diluted solution flows down (due to gravity) through the structural elements (destabilized fat particles, air cells, and remaining ice crystals). Senanayake et al. (2013) also attributed the higher melting rate due to the high total solids content and lower $\mathrm{pH}$ value, which favored the destabilization of the foam in fruit ice cream. Thus, this event may have occurred in this work, since ice cream 2 had higher total solids content and lower $\mathrm{pH}$ value.

\subsection{Texture analysis}

Table 4 shows that the firmness of ice cream 1 was higher $(p<0.05)$ than the ice cream 2. Mehditabar et al. (2019) and Acu et al. (2021) stated that many ingredients adding in the composition can modify the viscosity values of the ice creams. According to Muse \& Hartel (2004), several factors could affect the ice cream firmness parameter, such as the ice crystal size. Soukoulis et al. (2008) affirmed that instrumental firmness can be used as a measure of ice crystal growth since the number and size of ice crystals formed from the water available during freezing influences the formation and growth of these crystals during storage. Akalin et al. (2018) attributed the higher firmness to ice cream produced with different fibers due to the larger ice crystals and lower overrun. On the other hand, ice cream samples showed no difference $(p>0.05)$ for the parameter adhesiveness. However, ice cream 1 showed a higher $(p<0.05)$ gumminess. Dar \& Light (2014) verified that increasing this parameter has an undesirable effect on the appearance and texture of the ice cream, since after melting the ice cream in the mouth, there is a viscous sensation in the consumer's taste. Knowing this and according to the results obtained in this study (Table 4), ice cream 2 presented a gumminess lower than ice cream 1 , which is interesting to the consumer.

\subsection{Color analysis}

Table 4 shows that the parameters $\mathrm{L}^{*}, \mathrm{a}^{*}$, and $\mathrm{b}^{*}$ were all higher $(p<0.05)$ for the ice cream 2 . The higher luminosity $\left(L^{*}\right)$ for ice cream 2 can be explained by having a higher $(p<0.05)$ protein content in the product. Balthazar et al. (2015) verified that casein micelles have an affinity with fat particles and when they interact, they are responsible for the diffusion of incident light with a consequent increase in $\mathrm{L}^{\star}$ values. Regarding $\mathrm{a}^{\star}$ and $\mathrm{b}^{*}$ parameters, statistical differences were detected between ice creams 1 and 2, being that their negative and positive values indicated a tendency to green and yellow, respectively. Nozière et al. (2006) cited that the green color is due to riboflavin (vitamin B2), a green compound present in the aqueous phase of milk and that the fat-soluble pigments, especially $\beta$-carotene, are responsible for the yellowish coloration of milk. Balde \& Aider (2016) verified this same coloration trend in all parameters for skimmed milk obtained from the freeze concentration process. Therefore, it was perceptible that the block freeze concentration process had a great influence on the concentration of the compounds that are responsible for the color change of the ice cream since all the color parameters of ice cream 2 were statistically different to ice cream 1 . Despite the differences between $\mathrm{a}^{*}$ and $\mathrm{b}^{\star}$ parameters, it is important to highlight that both ice creams displayed low $\Delta \mathrm{E}^{\star}$ values. Martínez-Cervera et al. (2011) reported that when the value of the total color difference $\left(\Delta \mathrm{E}^{*}\right)$ is lower than 3 it cannot be visually perceived by the human eye. Thus, it was possible to verify (Table 4) that the color of ice cream samples was not affected.

\subsection{Rheological analysis}

Figure 4 shows the viscosity versus shear rate for ice cream 1 and 2 . It was found that the viscosity remains constant with increasing shear rate in ice cream, demonstrating a Newtonian behavior for all samples. Newtonian behavior can also be evaluated using data from the flow behavior index ( $n$ ) (Table 5), since $(n \cong 1)$ it is characterized as Newtonian behavior. Ice cream 2 had a higher $(p<0.05)$ viscosity (Figure 4 ; Table 5$)$, this fact is due to its higher $(p<0.05)$ total solids content. This behavior is in accordance with those verified by Akin et al. (2007) and

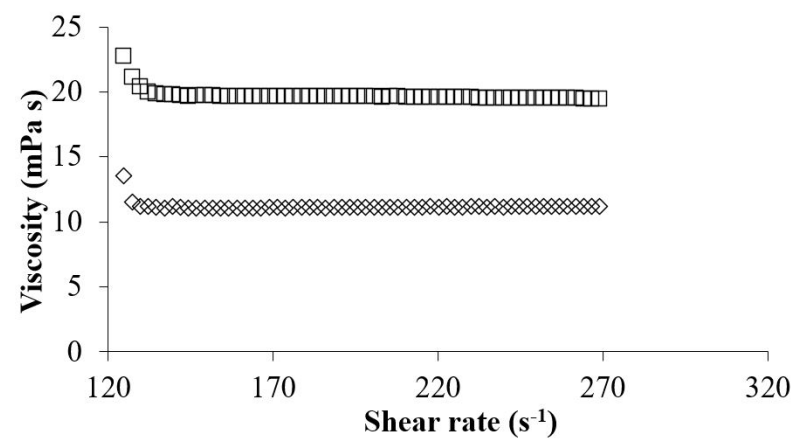

Figure 4. Viscosity versus deformation rate of the ice creams produced from skimmed milk (Ice cream 1) and concentrated milk (Ice cream 2). $\diamond=$ Ice cream $1 . \square=$ Ice cream 2

Table 5. Rheological parameters obtained using the Power Law $\left(\sigma=\mathrm{K}(\dot{\gamma})^{N}\right)$ and Casson model $\left(\sigma^{0.5}=\sigma^{00.5}+(\eta c \dot{\gamma})^{0.5}\right)$, viscosity and hysteresis area of the ice creams produced from skimmed milk (Ice cream 1) and concentrated milk (Ice cream 2).

\begin{tabular}{|c|c|c|c|c|c|c|c|c|}
\hline \multirow{3}{*}{ Sample } & \multicolumn{6}{|c|}{ Models } & \multirow{3}{*}{$\begin{array}{l}\text { Viscosity } \\
\text { (mPa s) }\end{array}$} & \multirow{3}{*}{$\begin{array}{l}\text { Hysteresis area } \\
\text { (unit) }\end{array}$} \\
\hline & \multicolumn{3}{|c|}{ Power Law } & \multicolumn{3}{|c|}{ Casson } & & \\
\hline & $\mathrm{K}\left(\mathrm{Pa} \mathrm{s}^{\mathrm{n}}\right)$ & $n$ & $R^{2}$ & $\sigma_{0}(\mathrm{~Pa})$ & $\eta_{c}(\mathrm{~Pa} \mathrm{~s})$ & $R^{2}$ & & \\
\hline Ice cream 1 & $0.0159 \pm 0.0086^{a}$ & $0.9815 \pm 0.0577^{\mathrm{a}}$ & 0.9982 & $0.0040 \pm 0.0030^{\mathrm{b}}$ & $0.0111 \pm 0.0008^{\mathrm{b}}$ & 0.9979 & $11.00 \pm 0.1866^{\mathrm{b}}$ & $1.9863 \pm 0.3587^{\mathrm{b}}$ \\
\hline Ice cream 2 & $0.0279 \pm 0.0019^{\mathrm{a}}$ & $0.9357 \pm 0.0117^{\mathrm{a}}$ & 0.9942 & $0.0188 \pm 0.0037^{\mathrm{a}}$ & $0.0169 \pm 0.0003^{\mathrm{a}}$ & 0.9923 & $20.00 \pm 0.1208^{\mathrm{a}}$ & $16.1921 \pm 0.6701^{2}$ \\
\hline
\end{tabular}

Results expressed as mean \pm standard deviation; ${ }^{\text {a-b }}$ Within a column, different superscript lowercase letters denote significant differences $(p<0.05)$ between the ice cream samples. K, consistency index; $n$, flow behavior index; $R^{2}$, determination coefficient; $\sigma_{0}$, Casson yield stress; $\eta_{c}$, Casson viscosity. 
Dogan et al. (2013) for ice creams with different sugar levels and xanthan gum, respectively.

It was observed that the Power Law and Casson models described the rheological behavior of the ice cream satisfactorily, since the correlation coefficient $\mathrm{R}^{2}>0.99$, in all cases (Table 5). When the Power Law model was used, there was no difference $(p>0.05)$ between the ice cream for the consistency index $(\mathrm{K})$ and flow behavior index $(n)$. These results demonstrated that the freeze concentration process did not alter the flow behavior and neither affected $\mathrm{K}$ and $n$ parameters. Aime et al. (2001) also mentioned that the consistency index $(\mathrm{K})$ is strongly related to the fat content of ice cream, once the increase in fat provides an increase in the K value. No difference $(p>0.05)$ was founded in the fat content of both ice creams manufactured in the present study, confirming consistency index behavior. The rheological parameters from the Casson model, Casson yield stress $\left(\sigma_{0}\right)$ and Casson viscosity $\left(\eta_{c}\right)$, were higher $(p<0.05)$ for ice cream 2 . This result also can be explained because ice cream 2 has a higher $(p<0.05)$ viscosity. Similar behavior was verified by Pinto et al. (2012) for frozen yogurt added inulin, which affirmed that the increase in the value of the Casson parameters may have been caused by the increase of apparent viscosity of samples, which probably occurred due to water retention by inulin.

Ice cream 2 presented a higher $(p<0.05)$ hysteresis area, indicating a change in the system structure, by the structural break down in a dispersion under shear. This difference can be explained by the higher $(p<0.05)$ viscosity and total solids content of ice cream 2. Hernández (1996) emphasized that a higher viscosity in a thixotropic fluid can demonstrate a larger hysteresis area than a less viscous fluid, even when occurs rupture in the less viscous fluid structure. Pinto et al. (2012) affirmed that the increase in the hysteresis area may be related to the increase in apparent viscosity of these samples for frozen yogurt added inulin.

\section{Conclusions}

The freeze concentration process proved to be an alternative for milk concentration. The highest process efficiency was verified in the first stage of freeze concentration. However, a drastic reduction was noted in the second and third stages, respectively. From the process efficiency results, the concentrated milk from the first stage of freeze concentration was used in the manufacture of the ice cream. Ice cream 2 , which was prepared with concentrated milk, had higher total solids, protein, ash, and carbohydrate content. On the other hand, there was no significant difference between samples for fat content. The use of concentrated milk promoted an increase in acidity and a decrease in $\mathrm{pH}$ of ice cream 2 , respectively. Higher luminosity and color tendency towards yellow and green were observed in ice cream 2.

Moreover, ice cream 2 had higher overrun, lower ice crystals, lower firmness, and lower gumminess. However, ice cream 2 had a higher melting rate. Adhesiveness parameter, air bubble size, and fat of ice cream showed no significant difference. The use of concentrated milk caused an increase in the viscosity and hysteresis area of ice cream 2 . The rheological measurements data adjusted well into the Power Law and Casson models and the ice creams showed a Newtonian fluid behavior.

Therefore, block freeze concentration showed to be a promising technology and can have the potential for use in the ice cream producing industries, because it is a method of easy manipulation and low cost, resulting in a final product with good chemical, physical, rheological, and microstructural properties.

\section{Acknowledgements}

The authors are grateful to CAPES (Coordination of Improvement of Higher Education Personnel, Finance code 001) by scholarship and the CNPq (National Counsel of Technological and Scientific Development, process number 405965/2016-8) by the financial support.

\section{References}

Acu, M., Kinik, O., \& Yerlikaya, O. (2021). Probiotic viability, viscosity, hardness properties and sensorial quality of synbiotic ice creams produced from goat's milk. Food Science and Technology (Campinas), 41(1), 167-173. http://dx.doi.org/10.1590/fst.39419.

Aider, M., De Halleux, D., \& Melnikova, I. (2009). Skim milk whey cryoconcentration and impact on the composition of the concentrated and ice fractions. Food and Bioprocess Technology, 2(1), 80-88. http:// dx.doi.org/10.1007/s11947-007-0023-0.

Aime, D. B., Arntfield, S. D., Malcolmson, L. J., \& Ryland, D. (2001). Textural analysis of fat reduced vanilla ice cream products. Food Research International, 34(2-3), 237-246. http://dx.doi.org/10.1016/ S0963-9969(00)00160-5.

Akalin, A. S., Kesenkas, H., Dinkci, N., Unal, G., Ozer, E., \& Kinik, O. (2018). Enrichment of probiotic ice cream with different dietary fibers: structural characteristics and culture viability. Journal of Dairy Science, 101(1), 37-46. http://dx.doi.org/10.3168/jds.201713468. PMid:29103712.

Akin, M. B., Akin, M. S., \& Kirmaci, Z. (2007). Effects of inulin and sugar levels on the viability of yogurt and probiotic bacteria and the physical and sensory characteristics in probiotic ice-cream. Food Chemistry, 104(1), 93-99. http://dx.doi.org/10.1016/j.foodchem.2006.11.030.

Association of Official Analytical Chemists - AOAC. (2019). Official methods of analysis of the Association of Official Analytical Chemists. Washington: AOAC

Ayed, C., Martins, S. I. F. S., Williamson, A. M., \& Guichard, E. (2018). Understanding fat, proteins and saliva impact on aroma release from flavoured ice creams. Food Chemistry, 267, 132-139. http://dx.doi. org/10.1016/j.foodchem.2017.10.127. PMid:29934147.

Balde, A., \& Aider, M. (2016). Impact of cryoconcentration on casein micelle size distribution, micelles inter-distance, and flow behavior of skim milk during refrigerated storage. Innovative Food Science \& Emerging Technologies, 34, 68-76. http://dx.doi.org/10.1016/j. ifset.2015.12.032.

Balthazar, C. F., Gaze, L. V., Azevedo da Silva, H. L., Pereira, C. S., Franco, R. M., Conte-Júnior, C. A., de Freitas, M. Q., \& de Oliveira Silva, A. C. (2015). Sensory evaluation of ovine milk yoghurt with inulin addition. International Journal of Dairy Technology, 68(2), 281-290. http://dx.doi.org/10.1111/1471-0307.12189.

Balthazar, C. F., Silva, H. L. A., Vieira, A. H., Neto, R. P. C., Cappato, L. P., Coimbra, P. T., Moraes, J., Andrade, M. M., Calado, V. M. A., Granato, D., Freitas, M. Q., Tavares, M. I. B., Raices, R. S. L., Silva, M. C., \& Cruz, A. G. (2017). Assessing the effects of different 
prebiotic dietary oligosaccharides in sheep milk ice cream. Food Research International, 91, 38-46. http://dx.doi.org/10.1016/j. foodres.2016.11.008. PMid:28290325.

Canella, M. H. M., Muñoz, I. B., Barros, E. L. S., Silva, C. C., Ploêncio, L. A. S., Daguer, H., \& Prudêncio, E. S. (2019). Block freeze concentration as a technique aiming the goatmilk concentration: fate of physical, chemical, and rheological properties. International Journal of Engineering Sciences \& Research Technology, 8(5), 87-104. http://dx.doi.org/10.5281/zenodo.2836603.

Cruxen, C. E. S., Hoffmann, J. F., Zandoná, G. P., Fiorentini, Â. M., Rombaldi, C. V., \& Chaves, F. C. (2017). Probiotic butiá (Butia odorata) ice cream: Development, characterization, stability of bioactive compounds, and viability of Bifidobacterium lactis during storage. Lebensmittel-Wissenschaft + Technologie, 75, 379-385. http:// dx.doi.org/10.1016/j.lwt.2016.09.011.

Dar, Y. L., \& Light, J. M. (2014). Food texture design and optimization. In A. Kilara (Ed.), Low fat ice cream. Chicago: IFT Press. http:// dx.doi.org/10.1002/9781118765616.

Di Criscio, T., Fratianni, A., Mignogna, R., Cinquanta, L., Coppola, R., Sorrentino, E., \& Panfili, G. (2010). Production of functional probiotic, prebiotic, and synbiotic ice creams. Journal of Dairy Science, 93(10), 4555-4564. http://dx.doi.org/10.3168/jds.20103355. PMid:20854989.

Ding, Z., Qin, F. G. F., Yuan, J., Huang, S., Jiang, R., \& Shao, Y. (2019). Concentration of apple juice with an intelligent freeze concentrator. Journal of Food Engineering, 256, 61-72. http://dx.doi.org/10.1016/j. jfoodeng.2019.03.018.

Dogan, M., Kayacier, A., Toker, Ö. S., Yilmaz, M. T., \& Karaman, S. (2013). Steady, Dynamic, Creep, and Recovery Analysis of Ice Cream Mixes Added with Different Concentrations of Xanthan Gum. Food and Bioprocess Technology, 6(6), 1420-1433. http://dx.doi. org/10.1007/s11947-012-0872-z.

Góral, M., Kozłowicz, K., Pankiewicz, U., Góral, D., Kluza, F., \& Wójtowicz, A. (2018). Impact of stabilizers on the freezing process, and physicochemical and organoleptic properties of coconut milkbased ice cream. Lebensmittel-Wissenschaft + Technologie, 92, 516522. http://dx.doi.org/10.1016/j.lwt.2018.03.010.

Granger, C., Leger, A., Barey, P., Langendorff, V., \& Cansell, M. (2005). Influence of formulation on the structural networks in ice cream. International Dairy Journal, 15(3), 255-262. http://dx.doi.org/10.1016/j. idairyj.2004.07.009.

Grigio, M. L., Durigan, M. F. B., \& Chagas, E. A. (2019). Different formulations of camu-camu popsicle: characterization, vitamin $\mathrm{C}$ and sensorial analysis of an opportunity to family agroindustry. Food Science and Technology (Campinas), 39(1, Suppl 1), 93-97. http://dx.doi.org/10.1590/fst.38417.

Gunathilake, M., Dozen, M., Shimmura, K., \& Miyawaki, O. (2014). An apparatus for partial ice-melting to improve yield in progressive freeze-concentration. Journal of Food Engineering, 142, 64-69. http:// dx.doi.org/10.1016/j.jfoodeng.2014.05.023.

Henao-Ardila, A., Quintanilla-Carvajal, M. X., \& Moreno, F. L. (2019). Combination of freeze concentration and spray drying for the production of feijoa (Acca sellowiana b.) pulp powder. Powder Technology, 344, 190-198. http://dx.doi.org/10.1016/j.powtec.2018.12.015.

Hernández, M. J. (1996). Caracterización reológica de hidrogeles de MCC-NaCMC + almidón Tixotropía y sinergismo (Phd thesis). Universidade de València, València, Spain.

Huppertz, T. (2010). Foaming properties of milk: A review of the influence of composition and processing. International Journal of Dairy Technology, 63(4), 477-488. http://dx.doi.org/10.1111/j.14710307.2010.00629.x.
Kalicka, D., Znamirowska, A., Pawlos, M., Buniowska, M., \& Szajnar, K. (2019). Physical and sensory characteristics and probiotic survival in ice cream sweetened with various polyols. International Journal of Dairy Technology, 72(3), 456-465. http://dx.doi.org/10.1111/14710307.12605.

Kamińska-Dwórznicka, A., Gondek, E., Laba, S., Jakubczyk, E., \& Samborska, K. (2019). Characteristics of instrumental methods to describe and assess the recrystallization process in ice cream systems. Foods, 8(4), 117. http://dx.doi.org/10.3390/foods8040117. PMid:30987379.

Lomolino, G., Zannoni, S., Zabara, A., Da Lio, M., \& De Iseppi, A. (2020). Ice recrystallisation and melting in ice cream with different proteins levels and subjected to thermal fluctuation. International Dairy Journal, 100, 104557. http://dx.doi.org/10.1016/j.idairyj.2019.104557.

Marshall, R. T., Goff, H. D., \& Hartel, R. W. (2003). Ice cream. In R. T. Marshall, H. D. Goff \& R. W. Hartel (Eds.), Calculation of ice cream mixes (6th ed.). New York: Springer Science+Business Media. http:// dx.doi.org/10.1007/978-1-4615-0163-3

Martínez-Cervera, S., Salvador, A., Muguerza, B., Moulay, L., \& Fiszman, S. M. (2011). Cocoa fibre and its application as a fat replacer in chocolate muffins. Lebensmittel-Wissenschaft + Technologie, 44(3), 729-736. http://dx.doi.org/10.1016/j.lwt.2010.06.035.

Mehditabar, H., Razavi, S. M. A., \& Javidi, F. (2019). Influence of pumpkin puree and guar gum on the bioactive, rheological, thermal and sensory properties of ice cream. International Journal of Dairy Technology, 73(2), 447-458. http://dx.doi.org/10.1111/1471-0307.12658.

Mostafavi, F. S., Tehrani, M. M., \& Mohebbi, M. (2017). Rheological and sensory properties of fat reduced vanilla ice creams containing milk protein concentrate (MPC). Journal of Food Measurement and Characterization, 11(2), 567-575. http://dx.doi.org/10.1007/ s11694-016-9424-y.

Muse, M. R., \& Hartel, R. W. (2004). Ice cream structural elements that affect melting rate and hardness. Journal of Dairy Science, 87(1), 1-10. http://dx.doi.org/10.3168/jds.S0022-0302(04)73135-5. PMid:14765804.

Nozière, P., Graulet, B., Lucas, A., Martin, B., Grolier, P., \& Doreau, M. (2006). Carotenoids for ruminants: From forages to dairy products. Animal Feed Science and Technology, 131(3-4), 418-450. http:// dx.doi.org/10.1016/j.anifeedsci.2006.06.018.

Okpala, C. O. R., Piggott, J. R., \& Schaschke, C. J. (2010). Influence of high-pressure processing (HPP) on physico-chemical properties of fresh cheese. Innovative Food Science \& Emerging Technologies, 11(1), 61-67. http://dx.doi.org/10.1016/j.ifset.2009.10.003.

Patel, M. R., Baer, R. J., \& Acharya, M. R. (2006). Increasing the protein content of ice cream. Journal of Dairy Science, 89(5), 1400-1406. http:// dx.doi.org/10.3168/jds.S0022-0302(06)72208-1. PMid:16606711.

Pinto, S. S., Fritzen-Freire, C. B., Muñoz, I. B., Barreto, P. L. M., Prudêncio, E. S., \& Amboni, R. D. M. C. (2012). Effects of the addition of microencapsulated Bifidobacterium BB-12 on the properties of frozen yogurt. Journal of Food Engineering, 111(4), 563-569. http:// dx.doi.org/10.1016/j.jfoodeng.2012.03.016.

Raventós, M., Hernández, E., Auleda, J., \& Ibarz, A. (2007). Concentration of aqueous sugar solutions in a multi-plate cryoconcentrator. Journal of Food Engineering, 79(2), 577-585. http://dx.doi.org/10.1016/j. jfoodeng.2006.02.017.

Sánchez, J., Hernández, E., Auleda, J. M., \& Raventós, M. (2011). Freeze concentration of whey in a falling-film based pilot plant: Process and characterization. Journal of Food Engineering, 103(2), 147-155. http://dx.doi.org/10.1016/j.jfoodeng.2010.10.009. 
Senaka Ranadheera, C., Evans, C. A., Adams, M. C., \& Baines, S. K. (2013). Production of probiotic ice cream from goat's milk and effect of packaging materials on product quality. Small Ruminant Research, 112(1-3), 174-180. http://dx.doi.org/10.1016/j.smallrumres.2012.12.020.

Senanayake, S. A., Fernando, S., Bamunuarachchi, A., \& Arsekularatne, M. (2013). Application of Lactobacillus acidophilus (LA 5) strain in fruit-based ice cream. Food Science \& Nutrition, 1(6), 428-431. http://dx.doi.org/10.1002/fsn3.66. PMid:24804052.

Silva, P. D. L., Bezerra, M. F., Santos, K. M. O., \& Correia, R. T. P. (2015). Potentially probiotic ice cream from goat's milk: characterization and cell viability during processing, storage and simulated gastrointestinal conditions. Lebensmittel-Wissenschaft + Technologie, 62(1), 452-457. http://dx.doi.org/10.1016/j.lwt.2014.02.055.

Sofjan, R. P., \& Hartel, R. W. (2004). Effects of overrun on structural and physical characteristics of ice cream. International Dairy Journal, 14(3), 255-262. http://dx.doi.org/10.1016/j. idairyj.2003.08.005

Soukoulis, C., Chandrinos, I., \& Tzia, C. (2008). Study of the functionality of selected hydrocolloids and their blends with $\kappa$-carrageenan on storage quality of vanilla ice cream. Lebensmittel-Wissenschaft + Technologie, 41(10), 1816-1827. http://dx.doi.org/10.1016/j. lwt.2007.12.009. 